\title{
Tinjauan Yuridis Tentang Penyalahgunaan Tanah Milik Daerah oleh Masyarakat Desa Daha Kabupaten Dompu
}

\author{
Mu`adz', Komang Sundara²
}

\author{
${ }^{1}$ Pendidikan Pancasila dan Kewarganegaraan, Universitas Muhammadiyah Mataram, muadz12@gmail.com \\ ${ }^{2}$ Pendidikan Pancasila dan Kewarganegaraan, Universitas Muhammadiyah Mataram, komangsundara@gmail.com
}

\begin{tabular}{l} 
INFO ARTIKEL \\
Riwayat Artikel: \\
Diterima: $\quad$ 17-Agustus- \\
2018 \\
Disetujui: $19-S e p t e m b e r-$ \\
2018 \\
\hline
\end{tabular}

Kata Kunci:

yuridis

penyalahgunaan

tanah

milik

daerah

masyarakat

\begin{abstract}
ABSTRAK
Abstrak: Tingkat penyalahgunaan tanah milik daerah oleh masyarakat Dompu makin marak. Hal tersebut mengharuskan peninjauan kembali terkiat aturan yang mengikat tentang tanah milik daerah yang digunakan secara bersama-sama atau untuk kepentingan umum. Tujuan penelitian untuk mengetahui bentuk-bentuk penyalahgunaan tanah milik daerah oleh masyarakat Desa Daha Kabupaten Dompu dan langkah-langkah yang ditempuh oleh pemerintah dan masyarakat dalam menyelesaikan penyalahgunaan tanah milik daerah oleh masyarakat Desa Daha Kabupaten Dompu. Jenis penelitian yang digunakan adalah yuridis empiris dengan pendekatan sosiologis hukum. Metode pengumpulan data menggunakan wawancara dan dokumentasi. Sedangkan jenis data yang digunakan adalah data primer. Sumber data diperoleh dari hasil wawancara dan dokumentasi. Hasil penelitian menunjukkan 1) bentuk-bentuk penyalahgunaan tanah milik daerah oleh masyarakat antara lain, (a) tanah milik pemda dijadikan jaminanhutang, (b) menjual lepas tanah milik pemda (c), menggadaikan kepada pihak lain yang dilakukan oleh 70 orang warga. 2) langkah-langkah yang ditempuh pemerintah dan masyarakat dalam menyelesaikan penyalahgunaan tanah milik daerah dilakukan dengan cara mediasi. Langkah yang ditempuh oleh Badan Pertanahan Nasional (BPN) antara lain (a) sepakat untuk menempuh proses mediasi (b) memahami masalah-masalah (c) membangkitkan pemilihan pemecahan masalah (d) mencapai kesepakatan (e) melaksanakan kesepakatan, bentuk mediasi yang dilakukan oleh Badan Pertanahan Nasional (BPN) adalah mediasi diluar pengadilan (Non Litigasi).
\end{abstract}

\begin{abstract}
The extent of misuse of land belonging to the Dompu community is increasingly marginal. This requires reconsideration of the binding rules on the land belonging to areas used jointly or in public interest. The purpose of research to know the forms of misuse of land belonging to the area by the community of Daha Village Dompu District and measures taken by the Government and the community in resolving the misuse of land belonging to the area by Daha Village community of Dompu District. The type of research used is the juridical empirical with a sociological approach to law. Methods of collecting data using interviews and documentation. While the type of data used is primary data. Data sources are obtained from interviews and documentation. The results showed 1) forms of misuse of land belonging to the region by the community, (a) the land belonging to the government was used as a vacuum, (b) sell the Land of the Government (c), mortgaged to other parties carried out by 70 people Citizens. 2) The steps traveled by the Government and the community in resolving the misuse of the land belonging to the area is done by mediation. The steps were taken by the National Land Agency (BPN), among others (a) agreed to take the mediation process (b) to understand the issues (c) to generate a resolution selection (d) to achieve an agreement (e) to execute the agreement, the form Mediation conducted by the National Land Agency (BPN) is mediation outside the courts (Non litigation).
\end{abstract}

\section{A. LATAR BELAKANG}

Tanah merupakan karunia Tuhan, dengan demikian selain memiliki nilai fisik, tanah juga mempunyai nilai kerohanian. Sebagai titipan Tuhan, perolehan dan pemanfaatannya harus sedemikian rupa sehingga dirasakan adil bagi semua pihak. Tanah adalah karunia Tuhan Yang Maha Esa bagi rakyat, bangsa dan Negara Indonesia, yang harus diusahakan, dimanfaatkan, dan dipergunakan untuk sebesar-besarnya kemakmuran rakyat[1]. Lebih lanjut dalam Pasal 2 ayat (1) dan (2) UUPA dinyatakan bahwa "atas dasar ketentuan dalam
Pasal 33 ayat (3) UUD 1945 dan hal-hal sebagai yang dimaksud dalam Pasal 1, bumi, air dan ruang angkasa, termasuk kekayaan alam yang terkandung di dalamnya itu pada tingkatan tertinggi dikuasai oleh negara, sebagai organisasi kekuasaan seluruh rakyat. Penguasaan dan pemanfaatan tanah yang diatur dalam Undang-Undang Pokok Agraria (UUPA) merupakan arah dari politik hukum pertanahan Indonesia yang bertujuan untuk menjamin terwujudnya kemakmuran bagi seluruh rakyat Indonesia[2].

Pendapatan asli daerah merupakan tulang punggung pembiayaan daerah, oleh karenanya kemampuan 
melaksanakan ekonomi di ukur dari besarnya kontribusi yang diberikan oleh pandapatan asli daerah terhadap total APBD, semakin besar kontribusi yang dapat diberikan oleh pendapatan asli daerah terhadap APBD berarti semakin kecil ketergantungan pemerintah daerah terhadap bantuan pemerintah pusat sehingga otonomi daerah dapat terwujud[3]. Tanah juga menjadi salah satu aset pendapatan daerah dan berkontribusi dalam menyumbang pendapatan asli daerah. Tanah adalah salah satu bentuk aset yang dimiliki Pemerintah Daerah[4]. Peruntukan dari tanah milik Pemerintah Daerah ada yang digunakan untuk kepentingan umum, misalnya taman terbuka dan ada yang digunakan untuk fungsi pelaksanaan pemerintahan[5]. Dengan ini, tanah milik daerah yang dimaksud adalah aset yang digunakan untuk fungsi pelaksanaan pemerintah.

Bahwa realitas yang terjadi di lapangan menunjukkan berbagai persoalan sengketa tanah, 1) Penggunaan tanah terlantar masih banyak ditemukan, 2) Banyak terjadi penyalahgunaan tanah milik daerah yang dilakukan oleh masyarakat, seperti pihak desa menggadekan tanah tersebut ke petani-petani, 3) Tumpang tindih kepemilikan lahan menjadi permasalahan yang banyak ditemukan. Wujud dari hal tersebut terlihat dari adanya perhatian khusus kepada kelompok masyarakat lemah melalui kebijakan pertanahan[2]. Sebagai contoh, dalam sebuah bidang tanah terdapat Tiga pihak yang mengaku sebagai pemilik sah. Masing-masing pihak memiliki sertifikat atas tanah tersebut, 4) Masih terjadi kesalahan atas pelaksanaan dan penerapan pengelolaan tanah milik daerah yang tidak sesuai peraturan perundangundangan, 5) Masih sering adanya penyelewengan fungsi tanah milik daerah digunakan tidak untuk sebagai mana mestinya, dan 6) Minimnya pengetahuan atas pedoman pengelolaan tanah milik daerah yang sesuai peraturan perundang-undangan pada SDM di pemerintah desa.

Terkait dengan persoalan tersebut, tentunya memerlukan solusi agar permasalahan tersebut tidak berlarut dan tidak menimbulkan korban jiwa, karena maslah sengeta tanah sering terjadi pertumpahan darah bahan banyak korban meninggal dunia karena perseturuan dan perkelahian. Dalam menyelesaikan sengketa, ada 3 cara yang dilakukan yakni menyelesaikan secara kekeluargaan, menyelesaikan melalui lembaga adat dan menyelesaikan di pengadilan negeri setempat[6]. Perencanaan aset daerah mengacu pada kebutuhan dan pemeliharaan barang milik daerah sebagaimana berpedoman pada standarisasi sarana dan prasarana kerja pemerintahan daerah yang ditetapkan dengan Peraturan Kepala Daerah dan standar harga yang ditetapkan dengan Keputusan Kepala Daerah[7].

Masalah sengketa tanah dan solusinya belum memenuhi aspirasi masyarakat adat. Karena solusi ditempuh melalui penengah instansi pemerintah, solusi dan proses negosiasi tergantung pada suasana politik dan ekonomi yang ada. Sebaiknya ada sistem pengadilan yang sebenarnya dapat dipercaya oleh masyarakat, agar solusi yang diberikan dapat menjadi pola dasar bagi solusi sengketa tanah selanjutnya[8]. Pengadaan tanah untuk kepentingan umum memerlukan persetujuan dari pihak yang berhak[9].

Demikian juga peran Badan Pertanahan Nasional menjelaskan 1) Penyelesaian terhadap sengketa pertanahan ini dapat dilakukan melalui dua cara, yaitu: (1) Penyelesaian Sengketa Melalui Jalur Pengadilan, dan; (2) Penyelesaian Sengketa Melalui Alternative Dispute Resolution (ADR). Badan Pertanahan Nasional sebagai Lembaga Non Departemen yang memiliki peranan penting dalam masalah pertanahan, memiliki fungsi untuk membantu menyelesaikan sengketa pertanahan, dalam melaksanakan fungsinya tersebut Badan Pertanahan Nasional beralaskan Pada Peraturan Kepala Badan Pertanahan Nasional Republik Indonesia Nomor 3 Tahun 2011 tentang Pengelolaan Pengkajian dan Penanganan Kasus Pertanahan. 2) Pasal 3 UndangUndang Nomor 5 Tahun 1960 tentang Peraturan Dasar Pokok-Pokok Agraria mengatur mengenai keberadaan tanah ulayat yang masih diakui apabila masih ada didalam lingkup masyarakat adat. Penjelesan mengenai tata cara penyelesaian tanah adat/hak ulayat sebenarnya telah diatur didalam Peraturan Menteri Agraria/Kepala Badan Pertanahan Nasional Nomor 5 Tahun 1999 tentang Pedoman Penyelesaian Masalah Hak Ulayat Masyarakat Hukum Adat[10].

Dengan berbagai permalahan di atas maka tujuan dalam aikel ini adal untuk mengidentifikasi bentukbentuk penyalahgunaan tanah milik daerah oleh masyarakat Desa Daha Kabupaten Dompu dan untuk menguraikan langkah-langkah yang ditempuh oleh pemerintah dan masyarakat dalam menyelesaikan penyalahgunaan tanah milik daerah oleh masyarakat Desa Daha Kabupaten Dompu.

\section{B. METODE PENELITIAN}

\section{Metode yang Digunakan}

Jenis penelitian yang digunakan adalah jenis penelitian yuridis empiris. Metode penelitian yuridis empiris yakni jenis penelitian dalam mendekati masalah yang diteliti dengan sifat hukum yang nyata atau sesuai dengan kenyataan yang hidup dalam masyarakat[11].

Dalam penggunaan metode yuridis empiris ini masih terdapat beberapa pendekatan yang dapat dipilih dalam rangka pemecahan masalah. Sehubungan dengan hal tersebut maka dalam penelitian ini, pendekatan yang dipilih adalah pendekatan sosiologis hukum.

\section{Subjek Penelitian}

Responden adalah seseorang atau individu yang akan memberikan respon terhadap pertanyaan yang diajukan oleh peneliti[12]. Informan adalah orang atau individu yang memberikan informasi data yang dibutuhkan oleh 
peneliti sebatas yang diketahuinya dan peneliti tidak dapat mengarahkan jawaban sesuai yang diinginkannya[12]. Narasumber adalah sesorang yang memberikan pendapat atas objek yang kita teliti[13].

3. Jenis Data dan Bahan Hukum

a. Jenis Data

Jenis data dalam kajian penelitian menjadi sangat mendasar untuk dilarifikasikan, mengingat masalah ini akan melandasi kegiatan selanjutnya. Pemahaman jenis data adalah suatu hal yang mutlak dalam penelitian. umumnya data terbagi atas data primer dan data sekunder[12].

1) Data primer adalah jenis data yang diperoleh dari tangan pertama atau jenis data yang diperoleh langsung dari lapangan

2) Data sekunder adalah data yang diperoleh langsung dari penelaahan kepustakaan atau penelaahan terhadap literatur atau bahan pustaka yang berkaitan dengan masalah atau materi penelitian yang sering disebut sebagai bahan hukum.

b. Bahan Hukum

Bahan hukum adalah bahan yang diperoleh dari kajian hukum[12]. Bahan hukum dibagi menjadi tiga yaitu sbagai berikut:

1) Bahan hukum primer yaitu bahan hukum yang dapat dilihat sebagai data yang merupakan perilaku hukum dari warga

2) Bahan hukum sekunder yaitu bahan hukum yang berasal dari kepustakaan,

3) Bahan hukum tersier adalah bahan hukum yang dapat memberikan penjelasan terhadap bahan hukum primer yang dapat berupa rancangan perundang-undangan, hasil penelitian, buku-buku teks dan berita internet.

4. Metode Pengumpulan Data

Metode pengumpulan data adalah cara yang digunakan oleh peneliti untuk mengumpulkan data, dalam hal ini adalah proses diperolehnya data dari sumber data, sumber data yang dimaksud berasal dari subjek penelitian[12]. Dalam penelitian ini, data yang dikumpulkan menggunakan metode sebagai berikut:

a. Metode Wawancara

Metode wawancara adalah sebuah dialog yang dilakukan oleh pewawancara[14]. Pendapat lain mengatakan bahwa metode wawancara adalah suatu teknik pengumpulan data yang dilakukan dengan cara tanya jawab antara penanya atau pewawancara dengan narasumber"[11].

\section{b. Metode Dokumentasi}

Metode dokumentasi yaitu mencari data mengenai hal-hal atau variabel yangberupa catatan, transkrip, buku, surat kabar, majalah, prasasti, agenda dan sebagainya[12]. Ahli lain mengungkapkan bahwa metode dokumentasi adalah suatu cara pengumpulan data berupa dokumentasi, serta menjadikan pencatatan sistemati[15].

\section{Metode Analisis Data}

Analisis data merupakan kegiatan dalam penelitian yang berupa melakukan kajian atau telaah terhadap hasil pengolahan data yang dibantu dengan teori-teori yang telah didapat sebelumnya[12].

a. Deskriptif

Sifat analis deskriptif adalah bahwa peneliti dalam menganalisis berkeinginan untuk memberikan gambaran atau pemaparan atas subjek dan objek penelitian sebagaimana hasil penelitian yang dilakukanya.

b. Evaluatif

Dalam analisis data yang bersifat evaluatif ini peneliti memberikan justifikasi atas hasil penelitian. Peneliti akan memberikan penelaian dari hasil penelitian, apakah hipotesis dari teori hukum yang diajukan diterima atau ditolak.

c. Perspektif

Sifat analisis ini dimaksudkan untuk memberikan argumentasi atas hasil penelitian yang telah dilakukanya. Argumentasi di sini dilakukan oleh peneliti untuk memberikan perspektif atau penelaian mengenai benar atau salah atau apa yang seyogianya menurut hukum terhadap fakta atau peristiwa hukum dari hasil penelitian tersebut.

\section{HASIL DAN PEMBAHASAN}

\section{Bentuk-Bentuk Penyalahgunaan Tanah Milik Daerah oleh Masyarakat Desa Daha Kabupaten Dompu}

Kasus-kasus penyalahgunaan tanah milik daerah disebabkan oleh beberapa faktor antara lain: faktor ekonomi, adanya kemudahan dalam mendapatkan modal, kekurangan modal, faktor sosial sehingga masyarakat melakukan tindakan penyalahgunaan tanah tersebut dan mendapatkan sanksi mengembalikan seluruh uang yang telah mereka terima yang sama besarnya dan tidak dapat lagi menggarap tanah tersebut selama 5 tahun kedepannya. Berdasarkan hasil penelitian beberapa bentuk penyalahgunaa tanah milik pemerintah daerah Dompu.

Tabel 1

Bentuk-bentuk Penyalahgunaan Tanah Milik Daerah oleh Masyarakat Desa Daha Kabupaten Dompu

\begin{tabular}{ccccc}
\hline No & Gang & $\begin{array}{c}\text { Luas } \\
\text { Tanah }\end{array}$ & $\begin{array}{c}\text { Luas } \\
\mathbf{M}^{2} / \text { Orang }\end{array}$ & $\begin{array}{c}\text { Jumlah } \\
\text { Orang }\end{array}$ \\
\hline 1 & Pertama & $10.000 \mathrm{M}^{2}$ & $1000 \mathrm{M}^{2}$ & 10 Orang \\
2 & Kedua & $10.000 \mathrm{M}^{2}$ & $1000 \mathrm{M}^{2}$ & 10 Orang \\
3 & Ketiga & $10.000 \mathrm{M}^{2}$ & $1000 \mathrm{M}^{2}$ & 10 Orang \\
4 & Keempat & $10.000 \mathrm{M}^{2}$ & $1000 \mathrm{M}^{2}$ & 10 Orang \\
5 & Kelima & $10.000 \mathrm{M}^{2}$ & $1000 \mathrm{M}^{2}$ & 10 Orang \\
6 & Keenam & $10.000 \mathrm{M}^{2}$ & $1000 \mathrm{M}^{2}$ & 10 Orang \\
7 & Ketujuh & $10.000 \mathrm{M}^{2}$ & $1000 \mathrm{M}^{2}$ & 10 Orang \\
8 & Kedelapan & $10.000 \mathrm{M}^{2}$ & $1000 \mathrm{M}^{2}$ & 10 Orang \\
9 & Kesembilan & $10.000 \mathrm{M}^{2}$ & $1000 \mathrm{M}^{2}$ & 10 Orang \\
10 & Kesepuluh & $10.000 \mathrm{M}^{2}$ & $1000 \mathrm{M}^{2}$ & 10 Orang \\
11 & Kesebelas & $10.000 \mathrm{M}^{2}$ & $1000 \mathrm{M}^{2}$ & 10 Orang
\end{tabular}


Jumlah $120.000 M^{2} \quad 120.000 M^{2}$

Menurut Suhaimin H. Umar. Selaku Kepala Desa Daha menjelaskan :

"Tanah yang diberikan hak sewa oleh Pemda kepada Masyarakat Desa Daha Kabupaten Dompu dijadikan jaminan utang pada Kreditur (Pemberi pinjaman),Kreditur ini bukanlah jenis lembaga pinjaman seperti Bank,Koperasi dan sejenisnya,tapi secara independen yang ada di kampung-kampung yang biasanya membungakan uang (Rentenir) disinilah letak salah satu penyalahgunaan tanah milik Pemda Kabupaten Dompu tersebut, pada hal status tanahnya hanya hak sewa untuk usaha pertanian yang diberikan oleh Pemda lewat Kepala Desa. Kasus ini diketahui oleh masyarakat dan pemerintah setelah pihak yang menjaminkan tanah tersebut tidak mampu membayar hutangnya ahirnya Kreditur melakukan eksekusi terhadap tanah tersebut, hal ini jelas bertentangan dengan peraturan yang berlaku maka dari itu eksekusi tidak bisa dilaksanakan". (Wawancara, 10 November 2016)

Berkaitan dengan penjelasan di atas maka sudah nampak jelas hal itu melanggar undang-undang yang berlaku seperti Undang-Undang Nomor 5 Tahun 1960 tentang Pokok-pokok Agraria dan peraturan pelaksana,karena sifatnya hak sewa mempunyai batas waktu tertentu dan peralihan maupun pembebannya kepada pihak lain otomatis memerlukan ijin dari pihak yang memilik yaitu Pemda Kabupaten Dompu.

Kasus masalah penyalahgunaan tanah milik Pemda juga dijelaskan oleh Bapak M. Tahir selaku ketua Badan Permusayawaratan Desa (BPD) menjelaskan:

"Kasus penyalahgunaan tanah Pemda oleh Masyarakat Desa Daha Kabupaten Dompu sangat bervariasi salah satunya adalah beberapa warga Desa Daha Menjual Lepas Tanah itu kepada pihak lain yang berada diluar Desa Daha tersebut dengan hanya menggunakan perjanjian Jual Beli dibawah tangan yang dibuat oleh masing-masing pihak, bahkan ada juga yang secara lisan. Khusus kejadian peralihan ini Masyarakat tersebut menggunakan modus akta dibawah tangan supaya transaksi berjalan dengan mudah dan tertutup." (Wawancarai, 15 November 2016)

Ketua Badan Permusyawaratan Desa (BPD) Kabupaten Dompu menyatakan kuatnya penyalahgunaan tanah milik Pemda Kabupaten Dompu yang dilakukan oleh beberapat Masyarakat Desa Daha, karena untuk masalah tanah sudah jelas UndangUndang Nomor 5 Tahun 1960 tentang Pokok-pokok Agraria dan peraturan pelaksana seperti Peraturan Pemerintah Nomor 10 tahun 1961 tentang pendaftaran tanah yang telah diubah dengah Peraturan Pemerintanh Nomor 24 tahun 1997 telah mengatur masalah secara terperinci tentangperalihan hak atas tanah.

Sementara menurut Muhammad Robin selaku Sekertaris Desa Daha Kabupaten Dompu menjelaskan

"Masalah Tanah Pemda Kabupaten Dompu yang disalahgunakan oleh Masyarakat Desa Daha yaitu berupa beberapa diantara masyarakat Desa Daha yang mendapat kesempatan hak Sewa atas tanah Pemda tersebut menggadaikan tanah tersebut dengan batas waktu lebih dari 7 (tujuh) tahun tanpa mengkonfirmasi ke Pemda, padahaln dalam pemberian haknya Masyarakat menyewa tanah Pemda Kabupaten Dompu itu maksimal 5 tahun untuk sekali kontrak, kemudian pemberi gadai tanah tersebut sudah meninggal setelah tanah tersebut selesai masa sewanya muncullah maslah, karena pihak yang menerima gadai merasa keberatan atas diambil alihnya tanah tersebut oleh Pemda Kabupaten Dompu karena pemegang gadai juga telah menjadikan tanah gadai itu pada salah seorang Kreditur tempat dia meminjam modal untuk usahanya." (Wawancara, 16 November 2016)

Demikian juga penjelasan Kemal Selaku kepala Badan Pertanahan Nasional (BPN) Kabupaten Dompu menjelaskan:

"Penyalahgunaan tanah milik Pemda Kabupaten Dompu yang dilakukan oleh Mayarakat Desa Daha memang benar terjadi, pihak BPN menerima pengaduan dari Kepala Desa Daha, setelah diterima maka dapat disimpulkan secara garis besar ada 3 (tiga) hal yang ditemukan yaitu: Tanah Pemda Kabupaten Dompu disalahgunakan oleh Masyarakat Desa Daha dengan (1) menjadikan tanah sebagai jaminan hutang, (2) menjual lepas tanah tersebut, dan (3) menggadaikan tanah tersebut dalam jangka 7 tahun, hal ini jelas sudah melanggar ketentuan peraturan perundang-undangan yang berlaku dan dalam hal ini BPN akan lebih dulu mengkaji apakah masalah ini merupakan kewenangan kementrian Agraria atau bukan itu tergantung pada data-data yang akan dikumpulkan." (Wawancara, 19 November 2016)

Penyalahgunaan Tanah Pemda oleh masyarakat Desa Daha Kabupaten Dompu, dapat diuraikan dalam bentuk tabel berikut ini:

Tabel 2

Penyalahgunaan Tanah Pemda oleh masyarakat Desa Daha

\begin{tabular}{cccccc} 
No & $\begin{array}{c}\text { Gan } \\
\text { g }\end{array}$ & $\begin{array}{c}\text { Luas } \\
\text { Tanah }\end{array}$ & $\begin{array}{c}\text { Luas } \\
\mathbf{M}^{2} / \text { Ora }\end{array}$ & $\begin{array}{c}\text { Juml } \\
\text { ah }\end{array}$ & $\begin{array}{c}\text { Keterang } \\
\text { an }\end{array}$ \\
\hline
\end{tabular}




\begin{tabular}{|c|c|c|c|c|c|}
\hline & & & ng & $\begin{array}{c}\text { Oran } \\
\mathbf{g}\end{array}$ & $\begin{array}{c}\text { Penyalah } \\
\text { gunaan } \\
\text { Tanah }\end{array}$ \\
\hline 1 & $\begin{array}{c}\text { Perta } \\
\text { ma }\end{array}$ & $\begin{array}{c}10.000 \\
\mathrm{M}^{2} / \text { Oran } \\
\mathrm{g}\end{array}$ & $\begin{array}{c}1.000 \\
\mathrm{M}^{2} / \text { Oran } \\
\mathrm{g}\end{array}$ & $\begin{array}{c}10 \\
\text { Orang }\end{array}$ & $\begin{array}{l}7 \text { Orang } \\
\text { yang } \\
\text { menggadai } \\
\text { kan tanah }\end{array}$ \\
\hline 2 & $\begin{array}{c}\text { Kedu } \\
\text { a }\end{array}$ & $\begin{array}{c}10.000 \\
\mathrm{M}^{2} / \text { Oran } \\
\mathrm{g}\end{array}$ & $\begin{array}{c}1.000 \\
\mathrm{M}^{2} / \text { Oran } \\
\mathrm{g}\end{array}$ & $\begin{array}{c}10 \\
\text { Orang }\end{array}$ & $\begin{array}{c}7 \text { Orang } \\
\text { yang } \\
\text { menggadai } \\
\text { kan tanah }\end{array}$ \\
\hline 3 & $\begin{array}{c}\text { Ketig } \\
\text { a }\end{array}$ & $\begin{array}{c}10.000 \\
\mathrm{M}^{2} / \text { Oran } \\
\mathrm{g}\end{array}$ & $\begin{array}{c}1.000 \\
\mathrm{M}^{2} / \text { Oran } \\
\mathrm{g}\end{array}$ & $\begin{array}{c}10 \\
\text { Orang }\end{array}$ & $\begin{array}{c}6 \text { Orang } \\
\text { yang } \\
\text { menjual } \\
\text { lepas tanah }\end{array}$ \\
\hline 4 & $\begin{array}{l}\text { Kee } \\
\text { mpat }\end{array}$ & $\begin{array}{c}10.000 \\
\mathrm{M}^{2} / \text { Oran } \\
\mathrm{g}\end{array}$ & $\begin{array}{c}1.000 \\
\mathrm{M}^{2} / \text { Oran } \\
\mathrm{g}\end{array}$ & $\begin{array}{c}10 \\
\text { Orang }\end{array}$ & $\begin{array}{c}6 \text { Orang } \\
\text { yang } \\
\text { menggadai } \\
\text { kan tanah }\end{array}$ \\
\hline 5 & $\begin{array}{l}\text { Keli } \\
\text { ma }\end{array}$ & $\begin{array}{c}10.000 \\
\mathrm{M}^{2} / \text { Oran } \\
\mathrm{g}\end{array}$ & $\begin{array}{c}1.000 \\
\mathrm{M}^{2} / \text { Oran } \\
\mathrm{g}\end{array}$ & $\begin{array}{c}10 \\
\text { Orang }\end{array}$ & $\begin{array}{l}5 \text { Orang } \\
\text { yang } \\
\text { menggadai } \\
\text { tanah }\end{array}$ \\
\hline 6 & $\begin{array}{c}\text { Keen } \\
\text { am }\end{array}$ & $\begin{array}{c}10.000 \\
\mathrm{M}^{2} / \text { Oran } \\
\mathrm{g}\end{array}$ & $\begin{array}{c}1.000 \\
\mathrm{M}^{2} / \text { Oran } \\
\mathrm{g}\end{array}$ & $\begin{array}{c}10 \\
\text { Orang }\end{array}$ & $\begin{array}{c}5 \text { Orang } \\
\text { menjamink } \\
\text { an tanah } \\
\text { sebagai } \\
\text { jaminan } \\
\text { hutang }\end{array}$ \\
\hline 7 & $\begin{array}{c}\text { Ketuj } \\
\text { uh }\end{array}$ & $\begin{array}{c}10.000 \\
\mathrm{M}^{2} / \text { Oran } \\
\mathrm{g}\end{array}$ & $\begin{array}{c}1.000 \\
\mathrm{M}^{2} / \text { Oran } \\
\mathrm{g}\end{array}$ & $\begin{array}{c}10 \\
\text { Orang }\end{array}$ & $\begin{array}{c}7 \text { Orang } \\
\text { yang } \\
\text { menggadai } \\
\text { kan tanah }\end{array}$ \\
\hline 8 & $\begin{array}{l}\text { Kede } \\
\text { lapa } \\
n\end{array}$ & $\begin{array}{c}10.000 \\
\mathrm{M}^{2} / \text { Oran } \\
\mathrm{g}\end{array}$ & $\begin{array}{c}1.000 \\
\mathrm{M}^{2} / \text { Oran } \\
\mathrm{g}\end{array}$ & $\begin{array}{c}10 \\
\text { Orang }\end{array}$ & $\begin{array}{c}5 \text { Orang } \\
\text { yang } \\
\text { menjual } \\
\text { lepas tanah }\end{array}$ \\
\hline 9 & $\begin{array}{c}\text { Kese } \\
\text { mbil } \\
\text { an }\end{array}$ & $\begin{array}{c}\text { 10.00o } \\
\mathrm{M}^{2} / \text { Oran } \\
\mathrm{g}\end{array}$ & $\begin{array}{c}1.000 \\
\mathrm{M}^{2} / \text { Oran } \\
\mathrm{g}\end{array}$ & $\begin{array}{c}10 \\
\text { Orang }\end{array}$ & $\begin{array}{c}8 \text { Orang } \\
\text { yang } \\
\text { menggadai } \\
\text { kan tanah }\end{array}$ \\
\hline 10 & $\begin{array}{c}\text { Kese } \\
\text { pulu } \\
\mathrm{h}\end{array}$ & $\begin{array}{c}\text { 10.00o } \\
\mathrm{M}^{2} / \text { Oran } \\
\mathrm{g}\end{array}$ & $\begin{array}{c}1.000 \\
\mathrm{M}^{2} / \text { Oran } \\
\mathrm{g}\end{array}$ & $\begin{array}{c}10 \\
\text { Orang }\end{array}$ & $\begin{array}{c}5 \text { Orang } \\
\text { yang } \\
\text { menjual } \\
\text { lepas tanah }\end{array}$ \\
\hline 11 & $\begin{array}{l}\text { Kese } \\
\text { belas }\end{array}$ & $\begin{array}{c}10.000 \\
\mathrm{M}^{2} / \text { Oran } \\
\mathrm{g}\end{array}$ & $\begin{array}{c}1.000 \\
\mathrm{M}^{2} / \text { Oran } \\
\mathrm{g}\end{array}$ & $\begin{array}{c}10 \\
\text { Orang }\end{array}$ & $\begin{array}{c}4 \text { Orang } \\
\text { yang } \\
\text { menjual } \\
\text { lepas tanah }\end{array}$ \\
\hline \multicolumn{2}{|c|}{ Jumlah } & $\begin{array}{c}120.000 \\
\mathrm{M}^{2}\end{array}$ & $\begin{array}{c}120.000 \\
\mathrm{M}^{2}\end{array}$ & $\begin{array}{c}120 \\
\text { Orang }\end{array}$ & 70 Orang \\
\hline
\end{tabular}

Jadi berdasarkan uraian di atas tentang bentukbentuk penyalahgunaan tanah milik daerah oleh masyarakat Desa Daha Kabupaten dompu, maka ada tiga (3) permasalahan antara lain :

a. Tanah milik pemda dijadikan jaminan hutang seluas 10.00oM2 (1 Ha) yang dilakukan oleh 10 (Sepuluh) Orang Warga.

b. Menjual lepas tanah milik pemda seluas 20.000M2 (2 Ha) yang dilakukan oleh 20 (Dua Puluh) Orang Warga.

c. Menggadaikan kepada pihak lain seluas 40.00oM2 (4 Ha) yang dilakukan oleh 40 (Empat Puluh) Orang Warga.

Dari 3 (tiga) permasalahan di atas menggambarkan bahwa memang benar masyarakat Desa Daha Kabupaten
Dompu telah melakukan penyalahgunaan tanah milik pemda atau dengan kata lain telah melakukan tindakan yang melawan hukum, itu dijelaskan pada UndangUndang Pokok-Pokok Agraria, karena hak sewa mempunyai batas waktu tertentu danperalihannya maupun pembebanannya kepada pihak lain otomatis memerlukan ijin dari pihak yang memiliki yaitu Pemda Kabupaten Dompu

\section{Langkah-Langkah Yang Ditempuh Oleh Pemerintah dan Masyarakat dalam Menyelesaikan Masalah Penyalahgunaan Tanah Milik Daerah Oleh Masyarakat Desa Daha Kabupaten Dompu}

Dari semua kasus penyalahgunaan tanah milik Pemda yang dilakukan oleh masyarakat Desa Daha Kabupaten Dompu hanya 30 kasus yang dapat terselesaikan secara musyawarah mufakat (kekeluargaan) sesuai dengan adat istiadat yang berlaku di dalam kehidupan masyarakat tersebut dan 40 kasus masih dalam proses dikarnakan tidak adanya kesepatan dari para pihak dan adanya yang merasa dirugikan karena permasalahan ini.

Berdasarkan peraturan Menteri Agraria No. 11 Tahun 2016 tentang penyelesaian kasus pertanahan menjelaskan bahwa:

Paragraf 1 Umum Pasal 37 berbunyi:

Penyelesaian Sengketa atau Konflik

sebagaimana dimaksud dalam Pasal 12 ayat (5)

dapat dilakukan melalui Mediasi.

Dalam hal salah satu pihak menolak untuk dilakukan Mediasi maka penyelesaiannya diserahkan kepada para pihak sesuai dengan ketentuan peraturan perundangundangan.

Paragraf 2 Pelaksanaan Mediasi Pasal 38 berbunyi: Apabila para pihak bersedia untuk dilakukan Mediasi sebagaimana dimaksud dalam Pasal 37 ayat (1), maka mediasi dilaksanakan berdasarkan prinsip musyawarah untuk mufakat bagi kebaikan semua pihak.

Dalam perjanjian sewa tanah milik Pemda tersebut bahwa jelas jangka waktu yang diberikan adalah selama 7 Tahun setelah 7 Tahun dikelola maka Pemda berhak mengambil kembali tanah tersebut dan sistem yang dalam perjanjian sewa tanah pemda yaitu sistem bayar dimuka yang dimana masyarakat yang ingin menyewa tanah pemda harus membayar dulu uang sejumlah yang disepakati tersebut.

Ada tiga kasus permasalahan tanah milik pemerintah daerah Dompu, yakni:

a. Kasus Tanah Milik Pemda Dijadikan Jaminan Hutang

Kasus menjaminkan tanah kepada rentenir terjadi hanya di 2 gang yaitu gang 6 dan gang 12 sebanyak 10 orang atau 10 kasus seluas 10.000M2/orang informasi ini diperoleh dari Bapak M. Sidik selaku Ketua RT o5 Desa Daha yang menyatakan: 
"Kasus menjaminkan tanah merupakan kasus yang memang cukup cepat menyebar di desa ini, kasus tersebut terjadi di akibat petani kesulitan mendapatkan pinjaman modal dari Bank karena proses yang lama dan syarat adminstrasi yang ketat karena masyarakat yang di 2 gang tersebut tidak mempunyai apaapa sebagai jaminan kebendaan untuk mendapatkan modal dan untuk besaran pinjaman yang mereka ambil adalah rata-rata Rp. 5.00o.ooo/ orang untuk luas 10.00oM2, meraka yang menjaminkan tanah tersebut dikenakan saksi setelah dimediasi di BPN berupa wajib mengembalikan uang dari kreditur tersebut setelah panen selesai dan tidak boleh ikut dalam pelelangan tanah tersebut untuk waktu 2 tahun kesimpulan tersebut diambil berdasarkan musyawarah dan mufakat" (Wawancarai, 24 april 2016).

Setelah mediasi berlangsung selama 30 hari kepada 10 kasus yang melakukan tindakan penyalahgunaan tanah milik Pemda hanya 5 kasus yang dapat terselesaikan secara musyawarah mufakat (kekeluargaan) seperti dalam kasus Bapak Ismail dan Bapak Nurhadiyansyah yang telah dapat terselesaikan.

Demikian pula pernyataan bapak Ismail selaku orang yang telah menerima tanah sebagai jaminan hutang tersebut menyatakan bahwa:

"iya memang benar kasus menjaminkan tanah Pemda antara saya dan Bapak Nurhadyansyah sudah terselesaikan melalui mediasi. Karena mediasi juga memiliki efekpositif untuk kami berdua, hubungan sosial kami berduapun tetap terjaga. Kesepakatan yang kami ambil pada saat mediasi berlangsung bahwa Bapak Nurhadiyansyah bersedia untuk mengembalikan uang saya dengan bunga 10\%" (Wawancarai, 30 November 2016 ).

Sedangkan 5 kasus masih dalam proses, dikarenakan tidak adanya kesepakatan antara para pihak yang bersangkutan dan adanya pihak yang merasa dirugikan karena permasalahan tersebut. Apa bila 10 kasus ini tidak dapat terselesaikan melalui mediasi (musyawarah mufakat) maka penyelesaian harus melalui pengadilan.

b. Kasus Menjual Lepas Tanah Milik Pemda

Kasus menjual lepas yang terjadi adalah sebanyak 20 kasus dengan luas masing-masing kasus seluas $10.000 \mathrm{M} 2 /$ orang yang terungkap di gang nomor 3,8 , 10 dan 11, Informasi ini diperoleh dari Bapak Mahfud selaku anggota BPD Desa Daha.

"Memang benar mereka dari gang yang berbeda nekat menjual lepas tanah tersebut karena beberapa masalah ekonomi yang melilit,mereka menjual dengan harga $R p$. 30.000.00o/10 are dan pembeli adalah 1 orang, setelah terungkap mereka sempat dilaporkan ke polisi oleh warga, namun kepala desa mengupayakan kasus ini dilakukan secara mediasi dulu, akhirnya mediasipun dilakukan dan mendapatkan 2 hal kesimpulan yaitu pertama mereka semua wajib mengembalikan seluruh uang dengan bunga 10\% untuk tiap bidang dan yang kedua adalah kami tidak bisa berkesempatan mendapatkan hak sewa atau hak pengelolaan dari tanah tersebut selama 5 tahu keseimpulan ini diambil berdasarkan musyawarah setempat" (Wawancarai, 22 November 2016)."

Mediasi telah dilakukan berlangsung selama 30 hari kepada 20 kasus yang melakukan tindakan penyalahgunaan tanah milik Pemda hanya 10 kasus yang dapat terselesaikan secara musyawarah mufakat (kekeluargaan) seperti dalam kasus Bapak Muhammad Abidin dan Bapak Nurdin yang telah dapat terselesaikan.

Menurut bapak Nurdin selaku orang yang telah menerima penjualan lepas tanah tersebut menyatakan bahwa:

"Kasus antara saya dan Bapak Nurdin sudah dapat terselesaikan dengan cara mediasi karena saya dan Bapak Nurdin itu mempunyai hubungan keluarga dan Bapak Nurdin juga telah menyanggupi untuk mengembalikan sejumlah uang yang telah saya berikan kepada dia kesepakatan ini kami ambil bersama" (Wawancarai, 28 November 2016).

Ada 10 kasus masih dalam proses, dikarnakan tidak adanya kesepakatan antara para pihak yang bersangkutan dan adanya pihak yang merasa dirugikan karena permasalahan tersebut. Apa bila 20 kasus ini tidak dapat terselesaikan melalui mediasi (musyawarah mufakat) maka penyelesaian harus melalui pengadilan.

c. Dalam Menggadaikan Kepada Pihak Lain

Kasus gadai yang terjadi adalah sebanyak 40 kasus yang terungkap di gang nomor 1, 2, 4, 5, 7 dan 9 . Informasi diatas diperoleh dari Bapak Abdullah selaku perwakilan yang menggadaikan tanah tersebut menyatakan:

"Memang benar kejadian tersebut kami menggadaikan tanah tersebut dengan harga yang rata-rata sama dan setelah tiba saatnya hal itupun terungkap dan kami sangat menyesalinya dan untuk solusinya sudah dilakukan mediasi di BPN dan kami berjumlah 40 orang dari gang yang berbeda mendapatkan sanksi yaitu mengembalikan seluruhnya uang gadai yang sama besarnya yaitu $R p$. 10.000.00o/10 are dan tidak bisa lagi mengikuti penggarapan tanah tersebut untuk 5 tahun kedepan" hal tersebut diambil berdasarkan hasil 
musyawarah dan mufakat setempat (Wawancarai, 21 November 2016).

Mediasi telah dilaksanakan selama 30 hari pada 40 kasus yang melakukan tindakan penyalahgunaan tanah milik Pemda hanya 15 kasus yang dapat terselesaikan secara musyawarah mufakat (kekeluargaan) seperti dalam kasus Bapak Mudar dan Bapak Surandi yang yang telah terselesaikan, dimana Bapak Muhdar menggadiakan tanah kepada Bapak Surandi dengan harga Rp. 10.000.ooo.

Demikian juga menurut Bapak Surandi selaku orang yang menerima gadai menyatakan bahwa:

"Dalam kasus penyelesaian gadai tanah ini, saya selaku penerima gadai dan Bapak Muhdar selaku penggadai tanah telah menyepakati untuk dilakukan mediasi yang dilakukan oleh pihak BPN Kabupaten Dompu dan kasus antara kami berdua telah dapat terselesaikan karena Bapak Muhdar telah mengembalikan uang sebesar Rp. 10.ooo.ooo kepada saya dengan bunga $10 \%$ sesuai dengan kesepakatan yang telah kami berdua sepakati bersama" (Wawancarai, 26 November 2016)

Sementara itu ada 35 kasus masih dalam proses, dikarnakan tidak adanya kesepakatan antara para pihak yang bersangkutan dan adanya pihak yang merasa dirugikan karena permasalahan tersebut. Apa bila 35 kasus ini tidak dapat terselesaikan melalui mediasi (musyawarah mufakat) maka penyelesaian harus melalui pengadilan.

Berdasarkan kasus menjual lepas di atas, maka ditemukan langkah-langkah yang ditempuh oleh Badan Pertanahan Nasional (BPN) untuk menyelesaikan kasus gadai tersebut adalah sebagai berikut:

1) Sepakat untuk menempuh proses mediasi yang dimaksud disini adalah yang dimana kedua belah pihak harus sepakat untuk menempuh proses mediasi, karena mediasi biasa dilakukan apabila kedua belah pihak yang bertikai sepak untuk di mediasi.

2) Memahami masalah-masalah yang dimaksud disini adalah seorang mediator harus memahami masalah masalah yang dihadapi oleh kedua belah pihak yang bertikai tersebut.

3) Membangkitkan pemilihan-pemilihan pemecahan masalah yang dimaksud disini adalah seorang mediator menyiapkan pemilihan pemilihan pemecahan masalah agar dapat disepakati oleh kedua belah pihak yang bertikai. Karena dalam hal ini seorang mediator tidak dapat menentukan keputusan yang berhak menentukan keputusan adalah para pihak yang bertikai tersebut dengan memusyawarahkannya bersama.

4) Mencapai kesepakatan yang dimaksud disini adalah setelah kedua belah pihak memusyawarahkan permasalahan tersebut sehingga tercapai sebuah kesepakatan antara mereka berdua yang tidak merugikan antara satu sama lain karena keputusan diambil oleh kedua belah pihak tersebut.

5) Melaksanakan kesepakatan yang dimaksud disini adalah setelah sudah ada kesepakatan yang diambil berdasarkan musyawarah tersebut, maka kedua belah pihak melaksanakan kesepakatan yang telah diambil berdasarkan musyawarah tersebut.

Hal-hal di atas merupakan langkah-langkah yang ditempuh oleh Pemerintah dan Masyarakat dalam menyelesaikan masalah penyalahgunaan tanah milik Daerah oleh Masyarakat desa Daha Kabupaten Dompu, setelah rentetan tahap pemeriksaan dan hasil investigasi lapangan, maka pihak mediator (BPN) Memaparkan hasil pada pihak-pihak yang berkepentingan.

Setelah mendengar penjelasan dari BPN tersebut maka pihak-pihak yang bersangkutan mempertimbangkan, setelah dipertimbangkan arahan dari BPN tersebut, maka masing-masing pihak sepakat untuk menerima putusan Badan Pertanahan Nasional (BPN) Kabupaten Dompu yang isinya antara lain sebagai berikut.

a) Masyarakat Desa Daha Kabupaten Dompu yang menyalahgunakan tanah milik Pemda Kabupaten Dompu mengakui keasalahan yang diperbuatnya dan menanggung segala resioko atas perbuatanya dalam bentuk ganti rugi berupa pengembalian sejumlah uang yang diminta pada saat menujual dan menggadaikan tanah kepada pembeli dan penerima gadai maupun yang menjaminkan tanah tersebutkepada Kreditur.

b) Keputusan ini diambil berdasarkan musyawarah dan mufakat antara pihak-pihak yang terkait yang memang tidak ada unsur paksaan dan tekanan dari pihak manapun karena proses Mediasi berjalan dengan transparan dan akuntabel.

c) Semua tanah yang disalahgunakan akan diambil alih kembali oleh Pemerintah Kabupaten Dompu.

Tabel 3

Penyalahgunaan Tanah Milik Pemda yang dilakukan oleh msyarakat Desa Daha Kabupaten Dompu

\begin{tabular}{|c|c|c|c|c|c|c|}
\hline \multirow[b]{2}{*}{ No } & \multirow[b]{2}{*}{ Gang } & \multirow[b]{2}{*}{$\begin{array}{l}\text { Luas } \\
\text { Tanah }\end{array}$} & \multirow[b]{2}{*}{$\begin{array}{c}\text { Luas } \\
\mathbf{M}^{2} / \text { Ora } \\
\text { ng }\end{array}$} & \multirow[b]{2}{*}{$\begin{array}{c}\text { Juml } \\
\text { ah } \\
\text { Oran } \\
\text { g }\end{array}$} & \multicolumn{2}{|c|}{ Ket } \\
\hline & & & & & $\begin{array}{c}\text { Ter } \\
\text { seles } \\
\text { aika } \\
\text { n }\end{array}$ & $\begin{array}{c}\text { Masi } \\
\text { h } \\
\text { dala } \\
\text { m } \\
\text { pros } \\
\text { es }\end{array}$ \\
\hline 1 & $\begin{array}{c}\text { Perta } \\
\text { ma }\end{array}$ & $\begin{array}{c}10.000 \\
\mathrm{M}^{2} / \text { Ora } \\
\text { ng }\end{array}$ & $\begin{array}{c}1.000 \\
\mathrm{M}^{2} / \text { Ora } \\
\text { ng }\end{array}$ & $\begin{array}{c}10 \\
\text { Orang }\end{array}$ & $\begin{array}{c}3 \\
\text { Oran } \\
g\end{array}$ & $\begin{array}{c}4 \\
\text { Oran } \\
g\end{array}$ \\
\hline 2 & $\begin{array}{c}\text { Kedu } \\
\mathrm{a}\end{array}$ & $\begin{array}{c}10.000 \\
\mathrm{M}^{2} / \text { Ora } \\
\text { ng }\end{array}$ & $\begin{array}{c}1.000 \\
\mathrm{M}^{2} / \text { Ora } \\
\text { ng }\end{array}$ & $\begin{array}{c}10 \\
\text { Orang }\end{array}$ & $\begin{array}{c}2 \\
\text { Oran } \\
\mathrm{g}\end{array}$ & $\begin{array}{c}5 \\
\text { Oran } \\
\mathrm{g}\end{array}$ \\
\hline 3 & $\begin{array}{c}\text { Ketig } \\
\text { a }\end{array}$ & $\begin{array}{c}10.000 \\
\mathrm{M}^{2} / \text { Ora } \\
\text { ng }\end{array}$ & $\begin{array}{c}1.000 \\
\mathrm{M}^{2} / \text { Ora } \\
\text { ng }\end{array}$ & $\begin{array}{c}10 \\
\text { Orang }\end{array}$ & $\begin{array}{c}3 \\
\text { Oran } \\
g\end{array}$ & $\begin{array}{c}3 \\
\text { Oran } \\
\mathrm{g}\end{array}$ \\
\hline 4 & $\begin{array}{c}\text { Keem } \\
\text { pat }\end{array}$ & $\begin{array}{c}10.000 \\
\mathrm{M}^{2} / \text { Ora } \\
\text { ng }\end{array}$ & $\begin{array}{c}1.000 \\
\mathrm{M}^{2} / \text { Ora } \\
\text { ng }\end{array}$ & $\begin{array}{c}10 \\
\text { Orang }\end{array}$ & $\begin{array}{c}2 \\
\text { Oran } \\
g\end{array}$ & $\begin{array}{c}4 \\
\text { Oran } \\
\mathrm{g}\end{array}$ \\
\hline 5 & Kelim & 10.000 & 1.000 & 10 & 3 & 2 \\
\hline
\end{tabular}




\begin{tabular}{|c|c|c|c|c|c|c|}
\hline & $\mathrm{a}$ & $\begin{array}{c}\mathrm{M}^{2} / \text { Ora } \\
\text { ng }\end{array}$ & $\begin{array}{c}\mathrm{M}^{2} / \text { Ora } \\
\text { ng }\end{array}$ & Orang & $\underset{\mathrm{g}}{\text { Oran }}$ & $\begin{array}{c}\text { Oran } \\
\mathrm{g}\end{array}$ \\
\hline 6 & $\begin{array}{c}\text { Keen } \\
\text { am }\end{array}$ & $\begin{array}{c}\text { 10.0oo } \\
\mathrm{M}^{2} / \text { Ora } \\
\text { ng }\end{array}$ & $\begin{array}{c}1.000 \\
\mathrm{M}^{2} / \text { Ora } \\
\text { ng }\end{array}$ & $\begin{array}{c}10 \\
\text { Orang }\end{array}$ & $\begin{array}{c}2 \\
\text { Oran } \\
\mathrm{g}\end{array}$ & $\begin{array}{c}3 \\
\text { Oran } \\
\mathrm{g}\end{array}$ \\
\hline 7 & $\begin{array}{l}\text { Ketuj } \\
\text { uh }\end{array}$ & $\begin{array}{c}10.000 \\
\mathrm{M}^{2} / \text { Ora } \\
\text { ng }\end{array}$ & $\begin{array}{c}1.000 \\
\mathrm{M}^{2} / \text { Ora } \\
\text { ng }\end{array}$ & $\begin{array}{c}10 \\
\text { Orang }\end{array}$ & $\begin{array}{c}2 \\
\text { Oran } \\
\mathrm{g}\end{array}$ & $\begin{array}{c}5 \\
\text { Oran } \\
\mathrm{g}\end{array}$ \\
\hline 8 & $\begin{array}{c}\text { Kedel } \\
\text { apan }\end{array}$ & $\begin{array}{c}10.000 \\
\mathrm{M}^{2} / \text { Ora } \\
\text { ng }\end{array}$ & $\begin{array}{c}1.000 \\
\mathrm{M}^{2} / \text { Ora } \\
\text { ng }\end{array}$ & $\begin{array}{l}10 \\
\text { Orang }\end{array}$ & $\underset{\mathrm{g}}{2}$ & $\begin{array}{c}3 \\
\text { Oran } \\
\mathrm{g}\end{array}$ \\
\hline 9 & $\begin{array}{c}\text { Kese } \\
\text { mbila } \\
\text { n }\end{array}$ & $\begin{array}{c}10.000 \\
\mathrm{M}^{2} / \text { Ora } \\
\text { ng }\end{array}$ & $\begin{array}{c}1.000 \\
\mathrm{M}^{2} / \text { Ora } \\
\text { ng }\end{array}$ & $\begin{array}{c}10 \\
\text { Orang }\end{array}$ & $\begin{array}{c}3 \\
\text { Oran } \\
\mathrm{g}\end{array}$ & $\begin{array}{c}5 \\
\text { Oran } \\
\mathrm{g}\end{array}$ \\
\hline 10 & $\begin{array}{c}\text { Kesep } \\
\text { uluh }\end{array}$ & $\begin{array}{c}10.000 \\
\mathrm{M}^{2} / \text { Ora } \\
\text { ng }\end{array}$ & $\begin{array}{c}1.000 \\
\mathrm{M}^{2} / \text { Ora } \\
\text { ng }\end{array}$ & $\begin{array}{c}10 \\
\text { Orang }\end{array}$ & $\begin{array}{c}2 \\
\text { Oran } \\
\mathrm{g}\end{array}$ & $\begin{array}{c}3 \\
\text { Oran } \\
\mathrm{g}\end{array}$ \\
\hline 11 & $\begin{array}{c}\text { Keseb } \\
\text { elas }\end{array}$ & $\begin{array}{c}\text { 10.0oo } \\
\mathrm{M}^{2} / \text { Ora } \\
\text { ng }\end{array}$ & $\begin{array}{c}1.000 \\
\mathrm{M}^{2} / \text { Ora } \\
\text { ng }\end{array}$ & $\begin{array}{c}10 \\
\text { Orang }\end{array}$ & $\begin{array}{c}3 \\
\text { Oran } \\
\mathrm{g}\end{array}$ & $\begin{array}{c}1 \\
\text { Oran } \\
\mathrm{g}\end{array}$ \\
\hline 12 & $\begin{array}{c}\text { kedu } \\
\text { abela } \\
\mathrm{s}\end{array}$ & $\begin{array}{c}\text { 10.0oo } \\
\mathrm{M}^{2} / \text { Ora } \\
\text { ng }\end{array}$ & $\begin{array}{c}1.000 \\
\mathrm{M}^{2} / \text { Ora } \\
\text { ng }\end{array}$ & $\begin{array}{c}10 \\
\text { Orang }\end{array}$ & $\begin{array}{c}3 \\
\text { Oran } \\
\mathrm{g}\end{array}$ & $\begin{array}{c}2 \\
\text { Oran } \\
\mathrm{g}\end{array}$ \\
\hline & & & & & $\begin{array}{c}30 \\
\text { Oran } \\
g\end{array}$ & $\begin{array}{c}40 \\
\text { Oran } \\
g\end{array}$ \\
\hline
\end{tabular}

\section{TEMUAN DAN DISKUSI}

Bentuk-bentuk penyalahgunaan tanah milik daerah oleh masyarakat Desa Daha Kabupaten dompu, maka ada tiga (3) permasalahan antara lain :

a. Tanah milik pemda dijadikan jaminan hutang seluas 10.00oM2 (1 Ha) yang dilakukan oleh 10 (Sepuluh) Orang Warga.

b. Menjual lepas tanah milik pemda seluas 20.000M2 (2 Ha) yang dilakukan oleh 20 (Dua Puluh) Orang Warga.

c. Menggadaikan kepada pihak lain seluas 40.00oM2 (4 Ha) yang dilakukan oleh 40 (Empat Puluh) Orang Warga.

Dari 3 (tiga) permasalahan di atas menggambarkan bahwa memang benar masyarakat Desa Daha Kabupaten Dompu telah melakukan penyalahgunaan tanah milik pemda atau dengan kata lain telah melakukan tindakan yang melawan hukum, itu dijelaskan pada UndangUndang Pokok-Pokok Agraria, karena hak sewa mempunyai batas waktu tertentu danperalihannya maupun pembebanannya kepada pihak lain otomatis memerlukan ijin dari pihak yang memiliki yaitu Pemda Kabupaten Dompu

Dengan demikian bahwa ada hubungannya dengan teori yang menjelaskan bahwa sengketa tanahmerupakan konflik antara dua pihak atau lebih yang mempunyai kepentingan berbeda terhadap satu atau beberapa obyek hak atas tanah yang dapat mengakibatkan akibat hukum bagi keduanya[16]. Pendapat yang sama[8], dia mengemukakan bahwa sengketa tanah merupakan konflik antara dua orang atau lebih yang sama mempunyai kepentingan atas status hak objek tanah antara satu atau beberapa objek tanah yang dapat mengakibatkan akibat hukum tertentu bagi para pihak.

Dari 70 kasus penyalahgunaan tanah milik Pemda yang dilakukan oleh masyarakat Desa Daha Kecamatan Hu,u Kabupaten Dompu hanya 30 kasus yang dapat terselesaikan secara musyawarah dan mufakat (kekeluargaan) sesuai dengan adat istiadat yang berlaku didalam masyarakat tersebut. Dalam hal ini masyarakat yang melakukan tindakan penyalahgunaan tanah milik Pemda dan masyarakat yang merasa dirugikan karena permasalahan tersebut, merasa tidak ada yang dirugikan, karena pihak yang melakukan tindakan penyalahgunaah tanah tersebut bersedia untuk mengembalikan sejumlah uang yang telah ia terima dari pihak yang dirugikan. Sedangkan sisanya yang masih dalam proses ada 40 kasus, dikarnakan tidak adanya kesepakatan antara para pihak dan adanya yang merasa dirugikan karena permasalahan tersebut.

\section{E. SIMPULAN DAN SARAN}

Hasil penelitian ini menunjukkan bahwa 1) bentukbentuk penyalahgunaan tanah milik daerah oleh masyarakat Desa Daha Kabupaten Dompu yaitu: penyalahgunaan tanah milik Pemda Kabupaten Dompu yang dilakukan oleh mayarakat desa Daha antara lain menjadikan tanah sebagai jaminan hutang, menjual lepas tanah tersebut, dan menggadaikan tanah tersebut dalam jangka 7 tahun, hal ini jelas sudah melanggar ketentuan peraturan perundang-undangan yang berlaku seperti Undang-Undang Nomor 5 tahun 1960 tentang Pokoko-Pokok ketentuan Agraria dan Undang-Undang Nomor 56/Prp 1960 tentang Landreform serta peraturan pelaksana lainya. 2) Langkah-langkah yang ditempuh oleh pemerintah dan masyarakat dalam menyelesaikan masalah penyalahgunaan tanah milik daerah oleh masyarakat desa Daha kabupaten Dompu yaitu hanya melalui Mediasi yang diprakarsai oleh Badan Pertanahan Nasioan (BPN) Kabupaten Dompu.

Pemerintah, agar lebih meningkatkan fungi pembinaan, pengawasan dan pengendalian terhadap Masyarakat Desa Daha Kabupaten Dompu agar tidak terulang kembali masalah penyalahgunaan tanah milik Pemda. Untuk masyarakat, diharapkan agar memahami dan mengetahui batas-batas hak dan kewajiban yang diberikan.

\section{UCAPAN TERIMA KASIH}

Penulis mengucapkan terima kasih kepada pihak Universitas Muhammadiyah Mataram yang senantiasa memberikan saran, masukan, dan dana kepada penulis sehingga artikel ilmiah ini selesai dengan tepat waktu.

\section{DAFTAR RUJUKAN}

[1] H. Djanggih and S. Salle, "Aspek Hukum Pengadaan Tanah bagi Pelaksanaan Pembangunan untuk Kepentingan Umum," 
Pandecta Res. Law J., vol. 12, no. 2, pp. 165-172, 2017.

[2] N. Ismail, "Arah politik hukum pertanahan dan perlindungan kepemilikan tanah masyarakat," $J$. Rechts Vinding Media Pembin. Huk. Nas., vol. 1, no. 1, pp. 33-51, 2012.

[3] E. Dewi, "Identifikasi Sumber Pendapatan Asli Daerah dalam Rangka Pelaksanaan Otonomi Daerah," 2002.

[4] U. Santoso, "Kewenangan Pemerintah Daerah dalam Penguasaan Atas Tanah,” J. Din. Huk., vol. 13, no. 1, pp. 99-108, 2013.

[5] A. Krisindarto, "Pengelolaan Aset Tanah Milik Pemerintah Kota Semarang," J. Pembang. Wil. KOTA, vol. 8, no. 4, pp. 403-411, 2012.

[6] M. Kaban, "Penyelesaian Sengketa Waris Tanah Adat Pada Masyarakat Adat Karo," Mimb. Hukum-Fakultas Huk. Univ. Gadjah Mada, vol. 28, no. 3, pp. 453-465, 2016.

[7] S. C. F. Tukunang, "Manajemen Aset Daerah Pada Dinas Pendapatan Pengelolaan Keuangan Dan Aset Daerah Kabupaten Kepulauan Siau, Tagulandang, Biaro," J. EMBA J. Ris. Ekon. Manajemen, Bisnis dan Akunt., vol. 4, no. 2, 2016.

[8] M. Sakai, "Solusi Sengketa Tanah di Era Reformasi Politik dan Desentralisasi Indonesia," Antropol. Indones., 2014.

[9] U. Santoso, "Penyelesaian Sengketa Dalam Pengadaan Tanah Untuk Kepentingan Umum," $J$. Perspekt., vol. 21, no. 3, 2016.

[10] F. Wowor, "Fungsi Badan Pertanahan Nasional Terhadap Penyelesaian Sengketa Tanah," LEX Priv., vol. 2, no. 2, 2014.

[11] P. Mahmud Marzuki, "Penelitian Hukum," Jakarta: Kencana Prenada Media, p. 55, 2005.

[12] M. F. N. Dewata and Y. Achmad, "Dualisme Penelitian Hukum Normatif dan Empiris," Yogyakarta: Pustaka Pelajar, 2010.

[13] Sugiyono, "Metode Penelitian kuantitatif kualitatif dan R dan D," Alf. Bandung, 2010.

[14] A. Suharsimi, "Prosedur Penelitian Suatu Pendekatan Praktik," Jakarta: Rineka Cipta, 2006.

[15] B. Ashshofa, "Legal Research Methods," Second Matter, Rineka Cipta, Jakarta, 2003.

[16] E. Syarief, Menuntaskan Sengketa Tanah Melalui Pengadilan Khusus Pertanahan. Kepustakaan Populer Gramedia, 2012. 